\title{
Influence of Long Term Fertilization on Yield and Active Pools of Soil Organic Carbon in an Typic Haplustepts under Groundnut-Wheat Cropping Sequence
}

\author{
Pradip Tripura $^{1 *}$, K.B. Polara ${ }^{1}$ and Mayur Shitab ${ }^{2}$ \\ ${ }^{1}$ Department of Agricultural Chemistry and Soil Science, ${ }^{2}$ Department of Agricultural \\ Statistics, Junagadh Agricultural University, Junagadh, 362001, Gujarat, India \\ *Corresponding author
}

\section{A B S T R A C T}

\begin{tabular}{|l|}
\hline K e y w o r d s \\
$\begin{array}{l}\text { Integrated nutrient } \\
\text { management, Long term } \\
\text { fertilizer experiment, } \\
\text { Yield, Active pools, Soil } \\
\text { organic carbon }\end{array}$ \\
\hline Article Info \\
\hline $\begin{array}{l}\text { Accepted: } \\
\text { 06 August 2018 } \\
\text { Available Online: } \\
\text { 10 September } 2018\end{array}$ \\
\hline
\end{tabular}

\section{Introduction}

Soil organic matter (SOM) plays a key role in the improvement of soil physical, chemical and biological properties. Conservation of the quantity and quality of soil organic matter (SOM) is considered a central component of sustainable soil management and maintenance of soil quality (Doran et al., 1996). Organic manure and inorganic fertilizer are the most common materials applied in agricultural
The effect of integrated nutrient management (INM) on yields and active pools of soil organic carbon (SOC) under groundnut-wheat cropping sequence of a Haplustepts soil was studied in a long term field experiment initiated since 1999 at Junagadh, Gujarat. Effect on varying doses of N, NP, NPK, NPK with FYM, Zn, S and Rhizobium on yields and active pools of SOC viz., soil microbial biomass carbon (SMBC), soil microbial biomass nitrogen (SMBN), soil microbial biomass phosphorus (SMBP), water soluble carbon (WSC), water soluble carbohydrate (WS-CHO) and dehydrogenase activity (DHA) after 16 year of groundnut-wheat crop sequence was studied. The result revealed that application of $50 \%$ NPK + FYM @ $10 \mathrm{t} \mathrm{ha}^{-1}$ to groundnut and $100 \%$ NPK to wheat significantly increased the groundnut yield and wheat yield. The highest and significant increase active pools of soil organic carbon was also observed under combine application of 50\% NPK + FYM @ $10 \mathrm{t}$ $\mathrm{ha}^{-1}$ to groundnut and $100 \% \mathrm{NPK}$ to wheat. These results indicate that long-term integrated use of FYM with chemical fertilizers or use of FYM alone exerted significant effect on the active pools of soil organic carbon. 
(Lal, 2006). Thus, maintaining SOC level is essential for agricultural sustainability. The concept of sustainable agricultural production emphasizes the importance of SOC management for food security and environment protection (Pan et al., 2009).

Plant residue is the primary source of SOM formation. The SOM is composed of series of fractions from very active and passive pools. These fractions act as highly sensitive indicators of soil fertility and productivity. In the sequence of humification process, first the decomposition products of the original plant residues are active fractions. The active fractions include soil microbial biomass; water soluble carbohydrates and it rarely comprise more than 10 to $20 \%$ of total SOM (Smith and Paul, 1990). It provides most of the readily accessible food for the soil organisms. Microbial biomass and its activity are usually positively correlated with SOM due to a dependence on both the quantity and quality of degradable carbon sources. Microbial biomass represents a significant part of the active SOM pool (Schnurer et al., 1985). The active fractions can be readily increased by the addition of fresh plant and animal residues, but they are also readily lost when such additions are reduced or tillage is intensified. Particularly, the presence of SOM is regarded as being critical for soil function and soil quality. Soil organic matter is one of our most important natural resources and from antiquity man has recognized that soil fertility may be maintained or improved by adding organic manures. Our objective was to study the changes of SOC fractions under a 16-year field experiment in Typic Haplustepts soil and to explain the relationship between different active pools of SOC fractions and crop yield. Improved understanding of active pools of soil organic carbon will provide valuable information for establishing sustainable fertilizer management systems to maintain and enhance soil quality.

\section{Materials and Methods}

\section{Study site description}

The AICRP LTFE was started in the year 1999 at Instructional Farm, College of Agriculture, Junagadh Agricultural University at Junagadh to study effect of continuous application of fertilizers ( $\mathrm{N}, \mathrm{P}$, and $\mathrm{K}$ ) and manure in a groundnut-wheat crop rotation.

In present work of LTFE soils, which was started 16 years back on Typic Haplustepts calcareous clay soil, there was addition of different amounts of major nutrients fertilizers, which changes in soil status in terms of major nutrients as well as soil organic carbon fraction content in soil.

The climate is tropical in Junagadh. The average annual temperature is $25.7{ }^{\circ} \mathrm{C}$ in Junagadh. Average annual rainfall is about $903 \mathrm{~mm}$ with 45 rainy days. About $91 \%$ of the annual rainfall is received during southwest monsoon season (June-September).

\section{Soil description}

The experiment soils are calcareous in nature derived from trap basalt, lime stone and sand stone under semi-arid climate. Taxonomically, the soil is classified as Haplustepts. The soil is dominated by smectite group of clay minerals, which give rise to mild cracking in dry season, due to which it is further classified as Typic Haplustepts at sub group level.

The experimental soils was calcareous $\left(\mathrm{CaCO}_{3-}-42.2 \%\right)$ in nature, alkaline in reaction $(\mathrm{pH} 8.2)$, free from salinity $\left(\mathrm{EC}_{2.5^{-}}\right.$ $0.19 \mathrm{dS} \mathrm{m}^{-1}$ ), had CEC $27.3 \mathrm{cmol}(\mathrm{p}+) \mathrm{kg}$ and clayey in texture. From fertility point of views, it was medium in available nitrogen $\left(271.23 \mathrm{~kg} \mathrm{ha}^{-1}\right)$, low in available phosphorus $\left(\mathrm{P}_{2} \mathrm{O}_{5}-25.51 \mathrm{~kg} \mathrm{ha}^{-1}\right)$ but high in available potassium $\left(\mathrm{K}_{2} \mathrm{O}-363.57 \mathrm{~kg} \mathrm{ha}^{-1}\right)$. 


\section{Treatments}

The long-term experiment included twelve fertilization treatments and each treatment had four replicates were arranged in a randomized block design. All plots were continuously under groundnut - wheat rotation from the beginning of the experiment.

The twelve treatments were $\mathrm{T}_{1}-50 \%$ NPK of recommended doses in Groundnut-wheat sequence, $\mathrm{T}_{2}-100 \% \mathrm{~N} \mathrm{P} \mathrm{K}$ of recommended doses in Groundnut -wheat sequence, $\mathrm{T}_{3}-150$ $\% \mathrm{~N} P \mathrm{~K}$ of recommended doses in Groundnut -wheat sequence, $\mathrm{T}_{4}-100 \% \mathrm{~N} \mathrm{P} \mathrm{K}$ of recommended doses in Groundnut -wheat sequence $+\mathrm{ZnSO}_{4} @ 50 \mathrm{~kg} \mathrm{ha}^{-1}$ once in three year to Groundnut only (i.e. 99, 02, 05 etc.), $\mathrm{T}_{5}-\mathrm{N} \mathrm{P} \mathrm{K}$ as per soil test, $\mathrm{T}_{6}-100 \% \mathrm{~N} \mathrm{P}$ of recommended doses in Groundnut -wheat sequence, $\mathrm{T}_{7}-100 \% \mathrm{~N}$ of recommended doses in Groundnut -wheat sequence, $\mathrm{T}_{8}-50$ $\%$ N P K of recommended doses+ FYM @ 10 $\mathrm{t} \mathrm{ha}^{-1}$ to Groundnut and $100 \%$ N P K to wheat, $\mathrm{T}_{9}$ - Only FYM @ $25 \mathrm{t} \mathrm{ha}^{-1}$ to Groundnut only, $\mathrm{T}_{10}-50 \% \mathrm{~N} \mathrm{P} \mathrm{K}$ of recommended doses + Rhizobium + PSM to Groundnut and $100 \% \mathrm{~N}$ $\mathrm{P} \mathrm{K}$ to wheat, $\mathrm{T}_{11}-100 \% \mathrm{~N} \mathrm{P} \mathrm{K}$ of recommended doses in Groundnut -wheat sequence ( $\mathrm{P}$ as SSP) and $\mathrm{T}_{12}$-Control.

\section{Soil sampling and analysis}

In the experiment, groundnut crop was grown during kharif 1999-2000 and wheat crop was grown during rabi 1999-2000. The soil samples were collected during three periods $\left(1^{\text {st }}\right.$ and $16^{\text {th }}$ years), initial year (1999- before Groundnut) and $16^{\text {th }}$ year (2015- after Wheat).

For the present study, soil samples were collected after harvest of wheat crop with the help of tube auger from the each plot of the above mentioned treatments representing the plough layer $(20 \mathrm{~cm})$. These soil samples were cleaned and air-dried. The soil samples, after air-drying, were ground with wooden mortar and pestle to pass through a $2 \mathrm{~mm}$ plastic sieve. The bulk soil samples were stored in polyethylene bags for chemical analysis.

The soil samples were analyzed for determining the active fraction of organic carbon on the basis of method mentioned below.

\section{Organic carbon}

Organic carbon was determined by wet oxidation method (Walkley and Black, 1935).

\section{Soil microbial biomass carbon}

Soil microbial biomass carbon was determined by chloroform-fumigation incubation method (Jenkinson and Powlson, 1976; Jenkinson and Ladd, 1981)

\section{Soil microbial biomass nitrogen}

Soil microbial biomass nitrogen was determined by chloroform-fumigation extraction method (Brookes et al., 1985)

\section{Soil microbial biomass phosphorous}

Soil microbial biomass phosphorous was determined by chloroform- fumigation incubation method (Brookes et al., 1982; Srivastava and Singh, 1988)

\section{Water soluble carbon}

Water soluble carbon was determined by acid extraction method (Meloon and Sommcr's, 1996)

\section{Water soluble carbohydrates}

Water soluble carbohydrates were determined by hydralytic extraction with $\mathrm{H}_{2} \mathrm{SO}_{4}$ (Chebire and Mundie, 1966) 


\section{Soil dehydrogenase activity}

Soil dehydrogenase activity was determined by anthrone extraction method (Casida et al., 1964)

\section{Statistical analysis}

All the analytical data recorded during the course of investigation were subjected to statistical analysis by using Randomized Block Design. Statistical analysis was completed using the SPSS 16.0 software package for Windows. Statistically significant differences were identified using analysis of variance ANOVA. As per the method outlined by Panse and Sukhatme (1985), the value of test at 5 and 1 per cent level of significant was determine and the values of SEm, CV per cent also calculate. The pooled analysis of two cycles of data was carried out as per procedure suggested by Cochran and Cox (1967).

\section{Results and Discussion}

\section{Groundnut pod yield}

The pod yield of groundnut were significantly influenced by various treatments in $16^{\text {th }}$ years result and maximum values of pod yield $\left(1146.75 \mathrm{~kg} \mathrm{ha}^{-1}\right)$ were recorded under application of $50 \%$ NPK of RDF + FYM @ $10 \mathrm{t} \mathrm{ha}^{-1}$ to groundnut-wheat sequence \& $100 \%$ NPK to wheat $\left(\mathrm{T}_{8}\right)$ followed by (1046.75 kg ha $\left.{ }^{-1}\right)$ FYM @ 25 t.ha $^{-1}$ to groundnut only $\left(\mathrm{T}_{9}\right)$. The pod yield of groundnut were not influenced significantly by various treatments of experiment, in $1^{\text {st }}$ year but numerically higher pod yield was recorded under $\mathrm{T}_{6}$ treatment $(100 \% \mathrm{NP}$ of recommended dose of Groundnut-Wheat sequence) in $1^{\text {st }}$ year (Table 1$)$. This finding result was support from the work of Redda and Kebede (2017) who observed that increased crop yield with combine application of FYM @ $9 \mathrm{t} \mathrm{ha}^{-1}$ and $75 \mathrm{~kg} \mathrm{ha}^{-1}$ inorganic fertilizer. Vala et al., (2017) also reported that the yield of groundnut was significantly increased with combine application of organic and inorganic fertilizers. Similarly Bhattacharyya et al., (2015) found that the crop yield was increased significantly by $74 \%$ over the control under the combined application of FYM + NPK.

\section{Groundnut haulm yield}

The haulm yields of groundnut were significantly influenced by various treatments in $16^{\text {th }}$ years result and maximum haulm yield (2614.66 and $2037.25 \mathrm{~kg} \mathrm{ha}^{-1}$ ) were recorded under $50 \%$ NPK of RDF + FYM @ $10 \mathrm{t} \mathrm{ha}^{-1}$ to groundnut-wheat sequence and $100 \%$ NPK to wheat $\left(\mathrm{T}_{8}\right)$ and this treatment also statistically at par with $\mathrm{T}_{2}, \mathrm{~T}_{3}, \mathrm{~T}_{4}$ and $\mathrm{T}_{9}$ treatment respectively. The haulm yield of groundnut did not influenced significantly by various treatments of experiment, in $1^{\text {st }}$ year, but numerically higher haulm yield was recorded under $\mathrm{T}_{2}$ treatment. Balaguravaih et al., (2005) reported that influence of long-term use of inorganic and organic manures increased sustainable production of groundnut yield. Similar Das et al., (2011) reported that FYM application@15 tha ${ }^{-1}$ along with 100 $\%$ NPK fertilizers and optimal dose of NPK (100 \%) along with Zn produced maximum yields in comparison to alone application of NPK fertilizers.

\section{Wheat grain yield}

The grain yields of wheat were significantly affected by various fertilization treatments of LTFE experiment in $1^{\text {st }}$ year as well as in 16 years. Significantly maximum values of grain yield (3407 kg ha ${ }^{-1}$ ) were obtained under treatment of $50 \%$ NPK of RDF + FYM @ 10 $\mathrm{t} \mathrm{ha}^{-1}$ to groundnut-wheat sequence \& $100 \%$ NPK to wheat $\left(\mathrm{T}_{8}\right)$ and this treatment was at par (3309.50 kg ha-1) with FYM @ $25 \mathrm{t} \mathrm{ha}^{-1}$ to groundnut only $\left(\mathrm{T}_{9}\right)$ during $16^{\text {th }}$ year, whereas 
significantly the higher grain yield of 1908.50 $\mathrm{kg} \mathrm{ha}^{-1}$ was recorded under $\mathrm{T}_{2}$ treatment (100 $\%$ NPK of RDF) and it was at par with $\mathrm{T}_{3}, \mathrm{~T}_{4}$, $\mathrm{T}_{5}, \mathrm{~T}_{6}, \mathrm{~T}_{8}$ and $\mathrm{T}_{11}$ treatment in first year results (Table 1). Verma et al., (2012) also reported similar results that the use of FYM along with $100 \%$ NPK increased crop productivity. The overall wheat grain yield increased after 16 year of experimentation compare to initial year. Rawal et al., (2015) observed that wheat grain yields were consistently higher in the NPK and FYM treatments than in treatments, where one or more nutrients were lacking. This result was also supported by Singh et al., (2017) who reported that highest productivity of wheat was recorded in the treatment comprising 100 $\%$ NPK + FYM in long term fertilizers experiment.

\section{Wheat straw yield}

The significantly higher straw yields (3911 and $4406 \mathrm{~kg} \mathrm{ha}^{-1}$ ) were registered with $\mathrm{T}_{8}$ treatment (50\% NPK of RDF + FYM @ $10 \mathrm{t}$ $\mathrm{ha}^{-1}$ to groundnut-wheat sequence \& $100 \%$ NPK to wheat) during $16^{\text {th }}$ year, respectively and this treatment was statistically at par with $\mathrm{T}_{9}$ treatment (FYM @ 25 t.ha ${ }^{-1}$ to groundnut only) during $16^{\text {th }}$ year. Whereas significantly higher straw yield (3090 kg ha ${ }^{-1}$ ) was recorded with $\mathrm{T}_{2}$ treatment which was at par with $\mathrm{T}_{3}$, $\mathrm{T}_{4}, \mathrm{~T}_{5}, \mathrm{~T}_{6}, \mathrm{~T}_{8}$ and $\mathrm{T}_{11}$ during $1^{\text {st }}$ year (Table 1$)$. The results corroborate the finding of Ravankar et al., (2004) who reported that the highest yield of wheat were recorded by 100 $\%$ NPK with 10 tonnes FYM ha ${ }^{-1}$ and the lowest under control. Sarawad and Sing (2004) was also reported that significant higher yield was observed under plots treated with $100 \%$ NPK + FYM than others. Similarly result was also found by Brar et al., (2015) who reported that continuous cropping and integrated use of organic and inorganic fertilizers increased soil $\mathrm{C}$ sequestration and crop yields.

\section{Organic Carbon (O. C.)}

The organic carbon was significantly affected by difference INM treatment in $16^{\text {th }}$ year and it was recorded higher under application of FYM @ 25 t/ha to groundnut only $\left(\mathrm{T}_{9}\right)$ followed by $50 \%$ NPK of RDF + FYM @ 10 $\mathrm{t} \mathrm{ha}^{-1}$ to groundnut-wheat sequence and $100 \%$ NPK to wheat $\left(T_{8}\right)$. In long term, there seems to be an increase in soil organic carbon after $16^{\text {th }}$ year experimentation (Table 2). This result is corroborated with the finding of Reddy et al., (2017) who reported that among the various treatment continuous use of farm yard manure with $100 \%$ NPK treatment resulted in highest organic carbon content in soil compared to other treatments. There was overall increased in organic carbon status of LTFE soils after $16^{\text {th }}$ year as compared to initial status $\left(1^{\text {st }}\right.$ year). In $1^{\text {st }}$ year the nonsignificantly higher value of organic carbon was observed under $50 \% \mathrm{NPK}$ of RDF in Groundnut-Wheat sequence $\left(\mathrm{T}_{1}\right)$ treatment followed by $\mathrm{T}_{6}(150 \% \mathrm{NPK}$ of $\mathrm{RDF}$ in Groundnut-Wheat sequence).

Pant et al., (2017) reported that long-term combine application of $100 \%$ NPK and FYM increased the organic carbon content in soil after crop harvest. The FYM application improved soil physical condition, ultimately root growth increases and more biomass added to the soil, seems to increases organic carbon status of the particular soil.

\section{Soil microbial biomass carbon}

With respect to status of SMBC, during 2000 and 2016, with treatment $\mathrm{T}_{8}(50 \%$ NPK of recommended doses in Groundnut -Wheat sequence + FYM @ $10 \mathrm{t} \mathrm{ha}^{-1}$ to Groundnut and $100 \%$ NPK to Wheat) showed the significantly higher value of SMBC (Table 3). In $1^{\text {st }}$ year result it is at par with $\mathrm{T}_{5}(\mathrm{NPK}$ as per soil test) and $\mathrm{T}_{9}$ (FYM @ $25 \mathrm{t} \mathrm{ha}^{-1}$ to Groundnut only). 
Table.1 Influence of different treatment on groundnut and wheat yield in $1^{\text {st }}$ year and $16^{\text {th }}$ year of LTFE soils

\begin{tabular}{|c|c|c|c|c|c|c|c|c|}
\hline \multirow[t]{3}{*}{ Treatment } & \multicolumn{4}{|c|}{ Groundnut Yield $\left(\mathrm{kg} \mathrm{ha}^{-1}\right)$} & \multicolumn{4}{|c|}{ Wheat Yield $\left(\mathrm{kg} \mathrm{ha}^{-1}\right)$} \\
\hline & \multicolumn{2}{|c|}{ Pod Yield } & \multicolumn{2}{|c|}{ Haulm Yield } & \multicolumn{2}{|c|}{ Grain Yield } & \multicolumn{2}{|c|}{ Straw Yield } \\
\hline & $\begin{array}{l}1^{\text {st }} \\
\text { year }\end{array}$ & $\begin{array}{l}16^{\text {th }} \\
\text { year }\end{array}$ & $\begin{array}{c}1^{\text {st }} \\
\text { year }\end{array}$ & $\begin{array}{l}16^{\text {th }} \\
\text { year }\end{array}$ & $\begin{array}{c}1^{\text {st }} \\
\text { year }\end{array}$ & $\begin{array}{l}16^{\text {th }} \\
\text { Year }\end{array}$ & $\begin{array}{l}1^{\text {st }} \\
\text { year }\end{array}$ & $\begin{array}{l}16^{\text {th }} \\
\text { year }\end{array}$ \\
\hline $\mathbf{T}_{1}$ & 962.00 & 816.25 & 1790.50 & 1640.75 & 1589.00 & 2093.00 & 2696.75 & 2802.50 \\
\hline$T_{2}$ & 984.75 & 941.50 & 2018.25 & 1781.00 & 1908.50 & 2758.50 & 3090.25 & 3526.75 \\
\hline $\mathbf{T}_{3}$ & 916.25 & 1012.75 & 1758.00 & 1960.50 & 1878.50 & 2893.00 & 2847.25 & 3728.75 \\
\hline $\mathrm{T}_{4}$ & 1048.00 & 951.50 & 1985.75 & 1969.75 & 1806.50 & 2694.50 & 2650.25 & 3419.25 \\
\hline $\mathbf{T}_{5}$ & 929.25 & 928.50 & 1676.50 & 1757.50 & 1856.50 & 2720.25 & 2819.50 & 3434.75 \\
\hline $\mathrm{T}_{6}$ & 1101.75 & 735.50 & 1969.50 & 1610.75 & 1718.75 & 2426.00 & 2696.75 & 2992.50 \\
\hline $\mathrm{T}_{7}$ & 927.50 & 622.00 & 1693.00 & 1370.00 & 1111.00 & 1562.50 & 1921.25 & 2056.75 \\
\hline $\mathrm{T}_{8}$ & 916.25 & 1146.75 & 1888.00 & 2037.25 & 1898.25 & 3407.00 & 2766.00 & 4406.25 \\
\hline $\mathrm{T}_{9}$ & 875.75 & 1046.75 & 1693.00 & 1873.50 & 1289.25 & 3309.50 & 2141.25 & 3966.75 \\
\hline$T_{10}$ & 963.50 & 856.00 & 2002.00 & 1709.00 & 1419.00 & 2566.50 & 2581.00 & 3307.50 \\
\hline$T_{11}$ & 1017.25 & 918.50 & 1871.50 & 1735.00 & 1608.75 & 2752.50 & 2963.00 & 3494.25 \\
\hline $\mathrm{T}_{12}$ & 968.25 & 709.75 & 1725.50 & 1400.25 & 1309.25 & 1678.75 & 2072.00 & 2231.25 \\
\hline MEAN & 967.54 & 890.48 & 1839.29 & 1737.10 & 1616.10 & 2571.83 & 2603.77 & 3280.60 \\
\hline S.Em. \pm & 74.12 & 46.13 & 131.39 & 90.22 & 107.36 & 132.29 & 155.89 & 176.34 \\
\hline C.D. at $5 \%$ & NS & 132.73 & NS & 259.58 & 309.12 & 380.62 & 448.86 & 507.37 \\
\hline C.V. \% & 15.32 & 10.36 & 14.29 & 10.39 & 13.29 & 10.29 & 11.97 & 10.75 \\
\hline
\end{tabular}

Table.2 Influence of different treatment on status of organic carbon in $1^{\text {st }}$ and $16^{\text {th }}$ year of LTFE soils

\begin{tabular}{|c|c|c|}
\hline \multirow[t]{2}{*}{ Treatment } & \multicolumn{2}{|c|}{ Organic Carbon (\%) } \\
\hline & $1^{\text {st }}$ year & $16^{\text {th }}$ year \\
\hline $\mathbf{T}_{1}$ & 0.615 & 0.621 \\
\hline $\mathbf{T}_{2}$ & 0.548 & 0.677 \\
\hline $\mathbf{T}_{3}$ & 0.510 & 0.668 \\
\hline $\mathbf{T}_{4}$ & 0.555 & 0.684 \\
\hline $\mathbf{T}_{5}$ & 0.525 & 0.670 \\
\hline$T_{6}$ & 0.600 & 0.621 \\
\hline $\mathbf{T}_{7}$ & 0.510 & 0.631 \\
\hline$T_{8}$ & 0.563 & 0.758 \\
\hline $\mathrm{T}_{9}$ & 0.525 & 0.790 \\
\hline $\mathbf{T}_{10}$ & 0.563 & 0.649 \\
\hline$T_{11}$ & 0.563 & 0.667 \\
\hline $\mathrm{T}_{12}$ & 0.540 & 0.631 \\
\hline MEAN & 0.551 & 0.672 \\
\hline S.Em. \pm & 0.048 & 0.015 \\
\hline C.D. at $5 \%$ & NS & 0.044 \\
\hline C.V. \% & 17.240 & 4.550 \\
\hline
\end{tabular}


Table.3 Influence of different treatment on status of soil microbial biomass carbon, soil microbial biomass nitrogen and soil microbial biomass phosphorus in

$1^{\text {st }}$ and $16^{\text {th }}$ year of LTFE soils

\begin{tabular}{|c|c|c|c|c|c|c|}
\hline \multirow[t]{2}{*}{ Treatment } & \multicolumn{2}{|c|}{ SMBC (mg kg $\left.{ }^{-1}\right)$} & \multicolumn{2}{|c|}{ SMBN (mg kg $\left.{ }^{-1}\right)$} & \multicolumn{2}{|c|}{ SMBP $\left(\mathrm{mg} \mathrm{kg}^{-1}\right)$} \\
\hline & $1^{\text {st }}$ year & $16^{\text {th }}$ year & $1^{\text {st }}$ year & $16^{\text {th }}$ year & $1^{\text {st }}$ year & $16^{\text {th }}$ year \\
\hline $\mathbf{T}_{1}$ & 87.72 & 122.52 & 6.70 & 10.27 & 12.53 & 10.54 \\
\hline $\mathbf{T}_{2}$ & 104.84 & 144.65 & 6.96 & 11.86 & 11.30 & 10.63 \\
\hline $\mathbf{T}_{3}$ & 101.02 & 227.91 & 7.04 & 12.51 & 14.42 & 11.03 \\
\hline $\mathbf{T}_{4}$ & 100.80 & 181.98 & 7.88 & 12.83 & 12.90 & 10.38 \\
\hline $\mathbf{T}_{5}$ & 232.51 & 218.29 & 8.00 & 11.84 & 10.10 & 9.68 \\
\hline$T_{6}$ & 184.33 & 209.48 & 6.95 & 10.23 & 11.72 & 9.33 \\
\hline $\mathbf{T}_{7}$ & 180.50 & 193.93 & 8.18 & 11.30 & 14.31 & 8.98 \\
\hline $\mathbf{T}_{8}$ & 243.01 & 268.68 & 10.18 & 17.17 & 16.82 & 12.07 \\
\hline $\mathrm{T}_{9}$ & 222.32 & 244.71 & 8.85 & 15.42 & 15.00 & 11.74 \\
\hline $\mathbf{T}_{10}$ & 196.30 & 222.33 & 7.08 & 12.13 & 14.02 & 11.21 \\
\hline $\mathbf{T}_{11}$ & 124.32 & 188.39 & 7.88 & 11.07 & 14.22 & 10.73 \\
\hline $\mathrm{T}_{12}$ & 86.50 & 112.26 & 6.40 & 9.63 & 8.51 & 7.51 \\
\hline MEAN & 155.35 & 194.59 & 7.67 & 12.19 & 12.99 & 10.32 \\
\hline S.Em. \pm & 9.45 & 7.68 & 0.40 & 0.59 & 0.47 & 0.46 \\
\hline C.D. at $5 \%$ & 27.20 & 22.08 & 1.14 & 1.70 & 1.35 & 1.32 \\
\hline C.V. \% & 12.17 & 7.89 & 10.36 & 9.69 & 7.23 & 8.89 \\
\hline
\end{tabular}

Table.4 Influence of different treatment on status of water soluble carbon, water soluble carbohydrate and dehydrogenase activity in $1^{\text {st }}$ and $16^{\text {th }}$ year of LTFE soils

\begin{tabular}{|c|c|c|c|c|c|c|}
\hline \multirow[t]{2}{*}{ Treatment } & \multicolumn{2}{|c|}{ WSC $\left(\mathrm{mg} \mathrm{kg}^{-1}\right)$} & \multicolumn{2}{|c|}{ WS-CHO (mg kg-1) } & \multicolumn{2}{|c|}{$\begin{array}{c}\text { DHA } \underset{\left.\mathrm{g}^{-1} \text { soil }\right)}{\left(\mu \mathrm{g} \mathrm{TPF}^{-1}\right.} 24 \mathrm{hr}^{-1} \\
\end{array}$} \\
\hline & $1^{\text {st }}$ year & $16^{\text {th }}$ year & $1^{\text {st }}$ year & $16^{\text {th }}$ year & $1^{\text {st }}$ year & $16^{\text {th }}$ year \\
\hline $\mathbf{T}_{1}$ & 24.00 & 33.75 & 36.50 & 43.25 & 36.50 & 32.25 \\
\hline$T_{2}$ & 30.00 & 38.25 & 37.50 & 45.00 & 42.50 & 41.25 \\
\hline$T_{3}$ & 38.00 & 41.00 & 38.50 & 44.50 & 30.00 & 33.75 \\
\hline $\mathbf{T}_{4}$ & 34.75 & 42.00 & 31.50 & 41.00 & 46.50 & 35.50 \\
\hline $\mathrm{T}_{5}$ & 29.50 & 40.75 & 41.50 & 45.50 & 33.50 & 38.00 \\
\hline$T_{6}$ & 34.50 & 38.25 & 40.50 & 47.50 & 38.25 & 33.75 \\
\hline $\mathbf{T}_{7}$ & 36.50 & 39.25 & 33.50 & 40.25 & 46.50 & 35.50 \\
\hline $\mathrm{T}_{8}$ & 44.50 & 52.50 & 46.50 & 54.25 & 52.50 & 44.25 \\
\hline $\mathbf{T}_{9}$ & 40.50 & 47.50 & 42.50 & 50.50 & 49.50 & 42.75 \\
\hline $\mathbf{T}_{10}$ & 21.50 & 33.75 & 27.50 & 37.00 & 31.50 & 32.75 \\
\hline$T_{11}$ & 28.50 & 35.75 & 41.00 & 44.25 & 40.50 & 33.75 \\
\hline $\mathrm{T}_{12}$ & 20.50 & 28.50 & 26.50 & 34.00 & 29.50 & 27.25 \\
\hline MEAN & 31.90 & 39.27 & 36.96 & 43.92 & 39.77 & 35.90 \\
\hline S.Em. \pm & 0.90 & 1.11 & 1.38 & 1.26 & 2.30 & 2.26 \\
\hline C.D. at $5 \%$ & 2.58 & 3.19 & 3.98 & 3.62 & 6.61 & 6.51 \\
\hline C.V. \% & 5.62 & 5.65 & 7.48 & 5.74 & 11.56 & 12.6 \\
\hline
\end{tabular}


Soil and crop management practices can greatly influences soil biological activity through their effect on quantity and quality of organic carbon added to soil. Use of FYM alone or in combination with chemical fertilizers significantly increased soil microbial biomass carbon (SMBC). There was overall increase in SMBC status of soil after 16 years as compared to initial status. Khan and Wani (2017) reported that significant build-up of soil microbial biomass carbon (SMBC) were maintained under FYM and integrated nutrient management involving FYM and NPK than unfertilized control plot in 0-15 and 15-30 cm soil depths. Similar results were also found by Verma and Mathur (2007). The supply of additional mineralizable and readily hydrolysable $\mathrm{C}$ due to organic manure application resulted in higher microbial activity and higher SMBC. It indicated that manure addition resulted in higher SMBC than inorganic fertilization or no fertilization (Control). The availability of soil microbial biomass carbon were significantly increased with the integrated application of organic manure (FYM @ $10 \mathrm{t}$ $\mathrm{ha}^{-1}$ ) and mineral fertilizers (100\% NPK) over control and other fertilizer treatment Katkar et al., (2011).

\section{Soil microbial biomass nitrogen}

The soil microbial biomass nitrogen content of soils showed significant difference in the years 2000 and 2016 (Table 3) with application of different INM treatment. The treatment $\mathrm{T}_{8}(50 \%$ NPK of recommended doses in Groundnut -Wheat sequence + FYM (a) $10 \mathrm{t} \mathrm{ha}^{-1}$ to Groundnut and $100 \%$ NPK to Wheat.) showed significantly higher value of SMBN in the year 2000 and 2016. High soil carbon content, more root proliferation and additional supply of $\mathrm{N}$ by FYM to microorganism might be responsible for increasing the level of SMBN. Kumari et al., (2011) also reported that continuous application of organic manure alone or in combination with inorganic fertilizer significantly influenced the soil microbial biomass nitrogen. FYM is not only rich in C but also in $\mathrm{N}$ and other macro and micronutrients. But the availability of nutrients to the crop from FYM is generally lower than $\mathrm{N}$ from inorganic fertilizer because of the slow release of organically bound $\mathrm{N}$ and volatilization of $\mathrm{NH}_{3}$ from the manure especially in calcareous soil (Beauchamp, 1983). Therefore, a combined application of FYM and fertilizer in the present study apparently provided supply of nutrients in balanced proportion which was reflected in terms of increased amounts of microbial biomass $\mathrm{N}$. Other alternate amendments, viz., $\mathrm{ZnSO}_{4}$ fertilizer application produced similar effect on microbial biomass $\mathrm{N}$ as that of NPK. In control, there was reduction in biomass $\mathrm{N}$ from that observed with optimal NPK for both crops (groundnut and wheat). With increase in fertilizer level from 100 to $150 \%$ there was a significant increase in biomass $\mathrm{N}$ over control. There was overall increase in SMBN status of soil after 16 years as compared to initial status. Because the SMBN was influence by added $\mathrm{N}$ through organic and in organic fertilizers as its produce large quantity of crop residues which provided available substrate for maintains of larger SMBN during the growing season (Salinas et al., 1997). Kaur et al., (2008) also observed that soil microbial biomass nitrogen was increased with an application of NPK and NPK + FYM than others treatment.

\section{Soil microbial biomass phosphorus}

The soil microbial biomass phosphorus content in soils of different treatments showed significant difference under the LTFE in the years 2000 and 2016 (Table 3). The results revealed that the treatment $\mathrm{T}_{8}(50 \% \mathrm{~N} \mathrm{P} \mathrm{K}$ of recommended doses in Groundnut -Wheat sequence+FYM@10 t ha ${ }^{-1}$ Groundnut and 
$100 \% \quad \mathrm{~N} \quad \mathrm{~K}$ to Wheat.) registered significantly higher value of SMBP (16.8 mg $\mathrm{kg}^{-1}$ ) in year 2000. Similarly the same treatment $\mathrm{T}_{8}$ showed significantly higher values $\left(12.07 \mathrm{mg} \mathrm{kg}^{-1}\right)$ of SMBP in year 2016 and it was at par with $\mathrm{T}_{9}, \mathrm{~T}_{10}$ and $\mathrm{T}_{3}$ treatment. There was overall decrease in SMBP status of soil after 16 years as compared to initial status. The continuous application of chemical fertilizers either alone or in combination with FYM increased the soil microbial biomass phosphorus (SMBP) content as compared to zero fertilized plots. Integrated use of organic and inorganic significantly increased the crop productivity and thereby provided substrates essential for microbial growth and activity which are probably responsible for this increase in SMBP. The low content in control plot could be due to no addition of any external input into the soil over the years and thereby poor crop productivity. Low content of SMBP in $100 \% \mathrm{~N}$ alone was observed. Reason attributed is the reduction of microbial cells due to absence of any phosphate substrate. The addition of higher levels of phosphorus through external source might have influenced the metabolism of microorganisms, which is probably responsible for higher levels of SMBP. Similar elevation in SMBP with the application of super-optimal dose of NPK and the rise in content of SMBP were also reported by Santhy et al., (2004). The result finding was also corroborated with Kumari et al., (2011) who observed that continuous application of organic manure alone or in combination with inorganic fertilizer significantly influenced the soil microbial biomass phosphorus.

\section{Water Soluble Carbon (WSC)}

Water soluble carbon (WSC) increased year wise irrespective of the treatments (Table 4). The results showed that the treatment $\mathrm{T}_{8}(50$
$\%$ NPK of recommended doses in Groundnut -Wheat sequence + FYM @ 10 t ha ${ }^{-1}$ Groundnut and $100 \%$ NPK to Wheat) registered significantly higher $(44.50$ and $52.50 \mathrm{mg} \mathrm{kg}^{-1}$ ) WSC during 2000 and 2016 respectively followed by treatment $\mathrm{T}_{9}$ (FYM @ $25 \mathrm{t} \mathrm{ha}^{-1}$ to Groundnut only). There was overall increase in WSC status of soil after 16 years as compared to initial status. Of course, this built-up was after many years as a result of large amount of clay particles enriched with water soluble carbon through addition of FYM and chemical fertilizers (Liang et al., 1995).

Highest water soluble carbon was observed in treatment receiving FYM alone followed by treatment with continuous addition of FYM in association with $100 \%$ NPK fertilizers, whereas the lowest content was found in controlled treatment in both the crop. The newly humified organic carbon through FYM addition might have sustained higher amount of WSC in sole FYM treatment, whereas higher amount of water soluble carbon in the $\mathrm{T}_{8}$ treatment (50\% NPK + FYM @ $10 \mathrm{t} \mathrm{ha}^{-1}$ to groundnut and $100 \%$ NPK to wheat) might be due to its origin and root exudates and lysates and its presence in soil solution.

The results are in agreement with Yagi et al., (2005) who attributed the same to the priming effect of the application of inorganic $\mathrm{N}$ or fresh organic material to the soil which stimulates the microbial activity and mineralization of $\mathrm{N}$ forms present in SOC helping thereby in decomposition of SOC with rapid release of WSC fraction.

This finding was also supported by Singh et al., (2003) who reported that the application of $100 \%$ NPK + FYM for about twenty eight years increased water soluble carbon by about 32 to $41 \%$ compared to the plot receiving only $100 \%$ NPK. Thus balance fertilization favored enrichment of water soluble carbon. 


\section{Water soluble carbohydrates}

The significant higher value of WSC as 46.50 and $54.25 \mathrm{mg} \mathrm{kg}^{-1}$ were registered with $\mathrm{T}_{8}$ treatment $(50 \%$ NPK of recommended doses in groundnut -wheat sequence + FYM @ $10 \mathrm{t}$ ha $^{-1}$ Groundnut and $100 \%$ NPK to Wheat) during 2000 and 2016 respectively (Table 4). Water soluble carbohydrates serves as source and sink for mineral nutrients and organic substrates in a short - term and as a catalyst for conversion of plant nutrients from over a longer period and therefore influence crop productivity and nutrient cycling (Kumari et al., 2011). There was overall increase in water soluble carbohydrate status of soil after 16 year as compared to initial status. The higher water soluble carbohydrate was observed in treatment which received FYM with mineral fertilizers in all span of LTFE experiment. This finding also corroborated with Mishra et al., (2008) who reported that continuous organic manure application or in combination with inorganic fertilizer, significantly influenced water soluble carbohydrates over $100 \%$ NPK and control.

\section{Dehydrogenase activity}

During 2000, treatment $\mathrm{T}_{8}(50 \%$ NPK of recommended doses in Groundnut -Wheat sequence + FYM @ $10 \mathrm{t} \mathrm{ha}^{-1}$ Groundnut and $100 \%$ NPK to Wheat) registered significantly higher value of dehydrogenase activity and it was at par with $\mathrm{T}_{4}, \mathrm{~T}_{7}$ and $\mathrm{T}_{9}$ treatment. In case of the year during 2016, treatment $\mathrm{T}_{8}$ showed higher value of dehydrogenase activity and it was at par with $\mathrm{T}_{9}, \mathrm{~T}_{2}$ and $\mathrm{T}_{5}$ treatment (Table 4). The addition of farmyard manure couple with mineral fertilization exerted a stimulating influence on preponderance of bacteria (Selvi et al., 2004). Similar result was found by Kaur et al., (2008) who observed that continuous application of fertilizers increased dehydrogenase activity significantly with an application of NPK and NPK + FYM than others treatment. The application of $\mathrm{N}$ fertilizers half as well as full doze although affect the dehydrogenase activity because of activity is strongly influenced by the presence of nitrate, which serves as an alternative electron acceptor resulting in low activity (Sneh et al., 1998). The dehydrogenase activity is increase with increasing level of mineral fertilizer doses from 50 to 150 NPK. The increase in DHA was $18.6 \%$ due to INM over $100 \%$ NPK through mineral fertilizers. The results are in line with the findings reported by Bhattacharyya et al., (2008), whereas the dehydrogenase activity increases 4-5 folds due to FYM application along with NPK. This result also supported by Katkar et al., (2011) who reported that the availability of dehydrogenase activity were significantly increased with the integrated application of organic manure (FYM @ 10 tones ha ${ }^{-1}$ ) and mineral fertilizers (100\% NPK) over control and other fertilizer treatment.

The result of present investigation showed that combine application of mineral fertilizers with FYM maintain soil organic carbon level in soil, crop yield and showed significant higher values as compare to control. However significant higher values of organic carbon status and crop yields were observed with application of $50 \%$ NPK + FYM @ $10 \mathrm{tha}^{-1}$ than other treatment. Integrated use of mineral fertilizers along with FYM significantly increased active pools of soil organic carbon and yield of groundnut and wheat as compare to unfertilized control and the initial values. The addition of NPK with FYM increased active fraction of organic carbon viz. SMBC, SMBN, SMBP, WSC, WS-CHO, DHA and yields of both groundnut and wheat under long term fertilization. Thus, NPK + FYM were the best option for increasing organic carbon status in soil and enhance crop yields. These results conclude that for sustainable crop production and maintaining soil quality, 
input of organic manure like FYM is of major importance and should be advocated in the nutrient management of intensive cropping system for improving soil fertility and biological properties of soils.

\section{Acknowledgements}

We would like to express our appreciation for the help and support from the researchers and staff in the department of agricultural chemistry and soil science. Especially, we would like to express our deep appreciation to Dr. M. S. Solanki and Dr. A. V. Rajani for collaboration and support to our research in the long-term fertilizer experiment.

\section{References}

Balaguravaih, D., Adinarayana, G., Prathap, S. and Reddy, T. Y. 2005. Influence of long-term use of inorganic and organic manures on soil fertility and sustainability of rainfed groundnut in Alfisols. Journal of the Indian Society of Soil Science, 53: 608-611.

Beauchamp, C. 1983. Response of corn to nitrogen in pre plant and side dress application of liquid dairy cattle manure. Canadian Journal of Soil Science. 63: 37-386.

Bhattacharyya, R., Prakash, K. S., Shrivastava, A. K., Gupta, H. S. and Mitra, S. 2008. Sustanability under combined application of mineral and organic fertilizers in a rainfed soyabeanwheat system of the Indian Himalayas. European Journal of Agronomy, 28 (1): 33-46.

Brar, B. S., Singh, J., Singh, G. and Kaur, G. 2015. Effects of Long Term Application of Inorganic and Organic Fertilizers on Soil Organic Carbon and Physical Properties in Maize-Wheat Rotation, Agronomy, 5: 220-238.

Brookes, P. C, Landman, A., Pruden, G. and
Jenkinson, D. S. 1985. Chloroform fumigation and release of soil "Nh a rapid direct extraction method to measure microbial biomass $\mathrm{N}$ in soil. Soil Biology and Biochemistry, 17: 837842.

Brookes, P. C, Powlson, D. S. and Jenkinson, D. S. 1982. Measurement of microbial biomass phosphorus in soils. Soil Biology and Biochemistry, 14: 319-321.

Casida, L. E., Jr. Klein, D. A. and Santoro, R. 1964. Soil dehydrogenase activity. Soil Science. 98: 371-378.

Chauhan, S. S. and Bhatnagar, R. K. 2012. Influence of long term use of organic and inorganic manures on soil fertility and sustainable productivity of wheat in Vertisols of Madhya Pradesh. An Asian Journal of Soil Science, 9(1): 113-116.

Chebhire and Mundie 1966. Hydralytic extraction of carbohydrates from soil by $\mathrm{H}_{2} \mathrm{SO}_{4}$. Soil Sci. 17 (2): compounds in soils. Pochvovedeme, 12: 1430-1439.

Cochran, W. G. and Cox, G. M. 1967. Experimental design. 2nd Edn. John Wiley and Sons Inc., New York.

Das, T., Ram, S. And Ram, N. 2011. Effect of long term application inorganic fertilizers and manure on yields, nutrients uptake and grain quality of wheat under rice-wheat cropping system in a Mollisols. Pantnagar Journal of Research, 9(2): 214-220.

Doran, J. W., Sarrantonio, M., Liebig, M. A. 1996. Soil health and sustainability. $A d v$ Agron, 56: 1-54.

Jenkinson, D. S. and Ladd, J. N. 1981. Microbial biomass in soil. Measurement and turnover In Soil Biochemistry (E. A. Paul and J. N. Ladd, Eds), pp 415471. Dekker, New York.

Jenkinson, D. S. and Powlson, D. S. 1976. The effects of biocidal treatments on metabolism in soil. A method for measuring soil biomass. Soil Biology and Biochemistry, 8: 189-202. 
Katkar, R. N., Sonune, B. A., and Kadu, P. R. 2011. Long-term effect of fertilization on soil chemical and biological cheracteristics and productivity under sorghum-wheat system in vertisol. Indian journal of Agriculture Science, 81 (8): 734-739.

Kaur, T., Brar, B. S. and Dhillon, N. S. 2008. Soil organic matter dynamics as affected by long-term use of organic and inorganic fertilizers under maizewheat cropping system, Nutr Cycl Agroecosyst, 81: 59-69.

Khan, A. M. and Wani, F. S. 2017. Effect of INM on Soil Carbon Pools in Rice - Oil Seed Cropping System under Temperate Conditions of Kashmir Valley. Int. J. Pure App. Biosci., 5 (6): 611-621.

Kumari, G. Mishra, B. Kumar, R., Agarwal, B. K. and Sing, B. P. 2011. Long term effect of manure, fertilizer and lime application on active and passive pools of soil organic carbon under maizewheat cropping system in an alfisols. Journal of Indian Society of Soil Science, 59(3): 245-250.

Lal, R. 2006. Enhancing crop yields in the developing countries through restoration of the soil organic carbon pool in agricultural lands, Land Degrad. Dev., 17: 197-209.

Liang, B. C, Gregorich, E. D. and Schnitzer, M. 1995. Mineral nitrogen accumulation in soils as affected by water-soluble organic carbon extracted from composted dairy manure. Commim. Soil Science \& Plant Analysis (USA). 26 (15-16): 2711-2723.

Meloon, S. J. and Sommcrs, R. S. 1996. Acid Extraction Method (Water Soluble Carbon) in Soil. Soil Biology and Biochemistry, 35: 511-513.

Mishra, B., Sharma, A., Singh, S. K., Prasad. J., Singh, B. P. 2008. Influence of continuous application of amendment to maize-wheat cropping system on dynamics of soil microbial biomass in alfisol of Jharkhand. Journal of Indian Society of Soil Science, 50 (1): 71-75.

Pan, G., Smith, P., and Pan, W. 2009. The role of soil organic matter in maintaining the productivity and yield stability of cereals in China, Agr. Ecosyst. Environ., 129: 344-348.

Panse, V. G. and Sukhatme, P. V. 1985. Statistical methods for agricultural worker (Fourth Edition). ICAR, New Delhi.

Pant, P. K., Ram, S. and Singh, V. 2017. Yield and Soil Organic Matter Dynamics as Affected by the LongTerm Use of Organic and Inorganic Fertilizers Under Rice-Wheat Cropping System in Subtropical Mollisols, Agric Res., 6(4): 399-409.

Ravankar, H. N., Singh, M. V., Sarap, P. A., 2004. Effect of long term fertilizer application and cropping on the sustenance of soil fertility and productivity under sorghum-wheat sequence in vertisol. Indian Farmers Digest: 40: 102-108.

Rawal, N., Chalise, D., Tripathi, J., Khadka, D. and Thapa, K. 2015. Wheat Yield Trend and Soil Fertility Status in Long Term Rice-Rice-Wheat Cropping System. Journal of Nepal Agricultural Research Council, 1:21-28.

Redda, A. and Kebede, F. 2017. Effects of Integrated use of Organic and Inorganic Fertilizers on Soil Properties Performance, using Rice (Oryza sativa L.) as an Indicator Crop in Tselemti District of north-western Tigray, Ethiopia. International Research Journal of Agricultural Science and Technology, 1(1): 6-14.

Reddy, C. V., Tiwari, A., Tedia, K., Verma, A. and Saxena, R. R. 2017. Effect Long term fertilizer experiments on Bulk Density, Crack Volume, Soil Organic Carbon stock and Carbon sequestration 
rate Rice crop. International Journal of Pure and Applied Bioscience, 5(4): 1051-1057.

Salinas, J. R., Hons, F. M. and Matocha, J. E. 1997. Long term effects of tillage and fertilization on soil organic matter dynamics. Soil Science Society of American Journal, 61(1): 152-159.

Santhy, P., Vijila, K., Selvi, D. and Dhakshinamoorthy, M. 2004. Studies on soil microbial biomass $\mathrm{P}$, labile $\mathrm{P}$ and phosphate activity under continuous intensive cultivation in an inceptisol. Annals-of-Agricultural-Research, $\quad 25$ (1): 38-42.

Sarawad, I. M. and Sing. D. 2004. Effect of Long Term Fertilizer Use on Yield and Nitrogen Uptake by Maize - Wheat Cowpea Sequence. Karnataka J.Agric.Sci., 17(4): 705-711.

Schnurer, L., Clarholm, M. and Rosswall, T. 1985. Microbial biomass and activity in an agricultural soil with different organic matter contents. Soil Biology and Biochemistry, 17: 611.

Selvi, D., Santhy, P., Dhakshinamoorty, M. and Maheshwari, M. 2004. Microbial population and biomass in rhizosphere as influenced by continuous intensive cultivation and fertilization in inceptisol. Journal of Indian Society of Soil Science, 52 (3): 254-7.

Singh, D., Sharma, R. P., Sankhyan, N. K. and Meena, S. C. 2017. Influence of long-term application of chemical fertilizers and soil amendments on physico-chemical soil quality indicators and crop yield under maize-wheat cropping system in an acid alfisol. Journal of Pharmacognosy and Phytochemistry, 6(3): 198-204.

Singh, M. V., Manna, M. C., Wanjari, R. H. Singh., Y. V. and Rajput, G. S. 2003. Comprehensive report, NATP-RRPS19- Organic pools and dynamics in relation to land use, tillage and agronomic practices for maintenance of soil fertility IISS, Bhopal pp. 1-92.

Smith, J. L. and Paul, E. A. 1990. The significance of soil microbial biomass estimations. Soil Biology. Vol. 6, Bollag, J. M. and Stotzuy, G. Eds., Marcel Dekker, New York 357.

Sneh, G., Chander, K., Mundra, M. C. and Kapoor, K. K. 1998. Influence of inorganic fertilizers and organic amendments on soil organic matter and soil microbial properties under tropical conditions. Biology and Fertility of Soils. 27: 196-200.

Srivastava, S. C. and Singh, J. S. 1988. Microbial $\mathrm{C}, \mathrm{N}$ and $\mathrm{P}$ in dry tropical forest soils: Effect of alternate land uses and nutrient flux. Soil Biology and Biochemistry. 23 (2): 117-124.

Vala, F. G., Vaghasia, P. M., Zala, K. P. and Buha, D. B. 2017. Effect of Integrated Nutrient Management on Productivity of Summer Groundnut (Arachis hypogaea L.), Int. J. Curr. Microbiology and App. Sci., 6(10): 1951-1957.

Verma G. and Mathur, A. K. 2007. Effect of continuous application of organic and inorganic fertilizers on micronutrient status in maize wheat system on Typic Ustochrept. Asian Journal of Soil Science, 2: 146-149.

Verma, G., Sharma, R. P., Sharma, S. P., Subehia, S. K. and Shambhavi, S. 2012. Changes in soil fertility status of maizewheat system due to long-term use of chemical fertilizers and amendments in an alfisol. Plant Soil Environment, 58(12): 529-533.

Verma, S. and Sharma, P. K. 2007. Effect of long-term manuring and fertilizers on carbon pools, soil structure, and sustainability under different cropping systems in wet-temperate zone of northwest Himalayas. Biol Fertility Soils, 44: 235-240. 
Vinther, F. P., Hansen, E. M., and Olesen, J. E. 2004. Effects of plant residues on crop performance, $\mathrm{N}$ mineralisation and microbial activity including field $\mathrm{CO}_{2}$ and $\mathrm{N}_{2} \mathrm{O}$ fluxes in unfertilised crop rotations, Nutr. Cycl. Agroecosys., 70: 189-199.

Walkley, A. and Black, I. A. 1935. An examination of methods for determining organic carbon and nitrogen in soils. Journal of Agriculture Science, 25: 589609.

Yagi, R., Ferreeira, M. F., Cruz, M. C. P. and Barbosa, J. C. 2003. Organic matter fraction and soil fertility under the influence of timing, vermicompost. Scientia Agricola, 60: 549-557.

\section{How to cite this article:}

Pradip Tripura, K.B. Polara and Mayur Shitab. 2018. Influence of Long Term Fertilization on Yield and Active Pools of Soil Organic Carbon in an Typic Haplustepts under GroundnutWheat Cropping Sequence. Int.J.Curr.Microbiol.App.Sci. 7(09): 781-794. doi: https://doi.org/10.20546/ijcmas.2018.709.094 